\title{
Geografia wydawnicza książek w Polsce (1999-2010)
}

\author{
Jadwiga Sadowska \\ Zakład Informacji Naukowej i Bibliotekoznawstwa \\ Uniwersytet $w$ Biatymstoku
}

\begin{abstract}
Abstrakt
Cel/teza: Celem artykułu jest przedstawienie geografii wydawniczej książek w Polsce w latach 1999-2010 (od ostatniego podziału administracyjnego kraju) według województw.

Koncepcja/Metody badań: Zastosowaną metodą badawczą jest analiza liczby tytułów książek zawartych w „Ruchu Wydawniczym w Liczbach” - oficjalnym roczniku polskiej statystyki wydawniczej. wyniki i wnioski: Na podstawie list rangowych produkcji poszczególnych typów książek pokazano zróżnicowanie terytorialne produkcji wydawniczej książek w Polsce. Stwierdzono, że największym ośrodkiem wydawniczym jest województwo mazowieckie i Warszawa, choć jej udział powoli zmniejsza się na rzecz innych miast. Kolejne miejsca zajmują: województwo małopolskie (Kraków), śląskie (Katowice), wielkopolskie (Poznań), dolnośląskie (Wrocław). Najniższe wskaźniki wydawnicze mają województwa: lubuskie (Zielona Góra), opolskie (Opole), warmińsko-mazurskie (Olsztyn), podlaskie (Białystok). Widoczny jest powolny proces decentralizacji wydawniczej.

oryginalność/wartość poznawcza: Przedstawione źródłowe dane statystyczne dotyczące produkcji książek w ujęciu geograficznym, chronologicznym i typologicznym dokumentują zmiany zachodzące na polskim rynku wydawniczym. W dotychczasowym piśmiennictwie brak jest tego typu analizy dotyczącej okresu 1999-2010.
\end{abstract}

Słowa kluczowe Geografia wydawnicza Polski (1999-2010), Książki w Polsce (1999-2010), „Ruch Wydawniczy w Liczbach", Statystyka książek w Polsce (1999-2010).

Otrzymany: 28.08.2013. Poprawiony: 08.11.2013. Zaakceptowany: 12.11.2013.

\section{Wprowadzenie}

Geografia wydawnicza (określana też jako topografia wydawnicza, topografia ruchu wydawniczego) (Nowak, 2003), bada terytorialny (przestrzenny) zasięg produkcji wydawniczej dokumentów, głównie książek i prasy ${ }^{1}$. Badania mogą obejmować poziom światowy, krajowy lub regionalny. Analiza miejsc wydania pozwala określić udział poszczególnych regionów i miejscowości w produkcji wydawniczej w danym roku, a analizy wieloletnie pokazują tendencje wydawnicze na określonym terytorium. Geografia wydawnicza dokumentuje stan liczbowy produkcji wydawniczej i jako taka jest przedmiotem badań bibliologicznych, natomiast jej pogłębioną interpretacją mogą zająć się kulturoznawcy, historycy, socjologowie. W krajach o gospodarce wolnorynkowej geografia wydawnicza jest odzwierciedleniem

1 Termin „geografia wydawnicza” stosuję przez analogię do terminu „geografia sprzedaży książek” występującego jako hasło w: Współczesne polskie księgarstwo : mały słownik encyklopedyczny. Wrocław : Ossolineum 1981, s.75. Określenia tego użył również Radosław Cybulski w tytule swojej publikacji Geografia sprzedaży Małej Encyklopedii Powszechnej PWN. Warszawa 1962. 
aktywności kulturalnej, naukowej i ekonomicznej społeczności lokalnych oraz instytucji związanych z książką na danym terenie. W krajach o rynku sterowanym geografia wydawnicza w jakimś stopniu odzwierciedla politykę kulturalną i naukową państwa wobec regionów w określonym czasie 2 .

Badania geografii wydawniczej, zwłaszcza uwzględniające aspekt historyczny i porównawczy, poszerzają wiedzę nie tylko o wielkości i rozmieszczeniu produkcji wydawniczej, lokalizacji instytucji wydawniczych, ale określają też poziom kultury piśmienniczej, infrastruktury kulturalnej, oświatowej, naukowej na danym terenie. Metoda topograficzna może być wykorzystywana szczególnie w badaniach bibliologicznych odnoszących się do świata książki w konkretnych miejscowościach czy regionach. O możliwościach zastosowania tej metody pisze Maria Kocójowa, odwołując się do swoich doświadczeń badania książki w Krakowie w drugiej połowie XIX w. (Kocójowa, 1995). W przypadku geografii wydawniczej dotyczącej regionu, dobrym źródłem badawczym są podmiotowe bibliografie regionalne i lokalne, które rejestrują publikacje powstające na jakimś terenie lub w danej miejscowości, a także wszelkiego rodzaju bibliografie księgarskie i katalogi wydawnicze.

Historyczna geografia wydawnicza, odtwarzająca lokalizację oficyn wydawniczych i drukarń w powiązaniu z repertuarem wydawniczym, daje obraz kształtowania się ośrodków kultury książki w kraju. Taki całościowy ogląd geografii wydawniczej w Polsce międzywojennej daje opracowanie Niny Kraśko pt. Instytucje wydawnicze w II Rzeczypospolitej, która w aneksie 3: Geografia instytucji wydawniczych zamieściła dane liczbowe dotyczące dorobku wydawniczego poszczególnych instytucji w podziale na województwa i miejscowości (Kraśko, s. 223-233).

Podstawą badań geografii wydawniczej są spisy bibliograficzne publikowanych dokumentów (narodowe, regionalne i lokalne), księgi akcesyjne i katalogi bibliotek, katalogi wydawnicze, spisy statystyczne, informatory adresowe dotyczące wydawców czy księgarzy.

Źródłem do badań produkcji wydawniczej w Polsce od pół wieku jest rocznik statystyczny „Ruch Wydawniczy w Liczbach”, opracowywany w Bibliotece Narodowej i ukazujący się od 1955 r. Zawarte w nim dane liczbowe oparte na bieżącej bibliografii narodowej, stanowią oficjalną statystykę państwową produkcji wydawniczej. Jest ona obliczana na podstawie egzemplarza obowiązkowego wpływającego do Biblioteki Narodowej i analizowana z autopsji według przyjętych kryteriów formalnych i treściowych.

„Ruch Wydawniczy w Liczbach” zawiera dane dotyczące wydawców, liczby tytułów wydawnictw zwartych i ciągłych, wysokości ich nakładu, miejsca wydania, liczby wydań, przekładów, typów publikacji, języka. Informacje o książkach w danym roku przedstawione są w postaci 26 tabel odnoszących się do książek ogółem, książek naukowych, zawodowych, podręczników szkolnych, książek popularnych, literatury pięknej. Wydawnictwa ciągłe przedstawione są w postaci 13 tabel odnoszących się do gazet i czasopism, a te z kolei analizowane są w podziale na poszczególne typy czasopism. Uzupełnieniem są zestawienia retrospektywne (10 tabel) od 1944 r.

Jednym z kryteriów jest miejsce wydania dokumentu. Odpowiednie tabele (tabela 2: Książki według miejsca wydania oraz tabela 29: Gazety i czasopisma według miejsca

2 Warto jednak zauważyć, że problemu geografii wydawniczej nie podjął Adam Bromberg w swoim cennym dziele Książki i wydawcy : ruch wydawniczy w Polsce Ludowej w latach 1944-1964. Wyd. 2, zm. i rozsz. Warszawa 1966. 
wydania) zawierają dane odnoszące się do liczby tytułów wydawnictw zwartych i ciągłych w poszczególnych województwach oraz miastach wojewódzkich. Pozwalają one analizować geografię wydawniczą w danym roku oraz w dłuższym czasie, praktycznie jednak w okresach odpowiadających podziałom administracyjnym kraju. Ostatni podział administracyjny Polski pochodzi z 1999 r., a jego rezultatem było utworzenie 16 województw w miejsce poprzednich 49 istniejących w latach 1975-1998. Są one zróżnicowane zarówno pod względem powierzchni, liczby ludności, jak też infrastruktury gospodarczej, kulturalnej, oświatowej, naukowej. Znajduje to odzwierciedlenie również w działalności wydawniczej.

Na podstawie obserwacji, z dużym prawdopodobieństwem można wskazać województwa i miejscowości, które w Polsce mają najwyższą produkcję wydawniczą. Bez wątpienia jest to Warszawa i województwo mazowieckie oraz Kraków i województwo małopolskie. Obserwacje, choć może i trafne, nie są jednak wystarczające do potwierdzenia rzeczywistego stanu rzeczy, odzwierciedlonego w liczbie wydawanych tytułów w poszczególnych regionach. Niewątpliwie, od 1990 r. trwa w Polsce decentralizacja rynku wydawniczego, wydawcy przenoszą się do mniejszych ośrodków, zmienia się udział poszczególnych regionów i miast w globalnej produkcji wydawniczej. Zjawisko to jednak przebiega niejednolicie. Dlatego podjęcie tematu geografii wydawniczej w Polsce wydaje się interesujące, pozwoli bowiem odpowiedzieć bardziej precyzyjnie i wiarygodnie na pytanie o tendencje rozwojowe rynku wydawniczego w poszczególnych województwach, miastach i regionach Polski w ostatnich kilkunastu latach.

Celem artykułu jest analiza produkcji wydawniczej książek w Polsce w ujęciu terytorialnym (regionalnym), chronologicznym i typologicznym (książki naukowe, popularne, literatura piękna). Punktem wyjścia są dane dotyczące liczby tytułów wydawanych książek zawarte w „Ruchu Wydawniczym w Liczbach”. Efektem są listy rangowe województw wskazujące ich miejsce w globalnej produkcji wydawniczej książek w kraju. W artykule nie podjęto spraw związanych z analizą wysokości nakładów, ani też sprzedażą książki w poszczególnych województwach. Nie starano się też wnikać w uwarunkowania ekonomiczne, które również rzutują na rynek wydawniczy. Ten aspekt polskiego rynku wydawniczego $\mathrm{w}$ powiązaniu z wysokością produktu krajowego (РКВ) był przedmiotem badania Piotra Nowaka (Nowak, 2003).

\section{Produkcja wydawnicza książek w województwach}

Liczba wydawanych rocznie książek w poszczególnych województwach jest zróżnicowana, a na lokalizację oficyn wydawniczych mają wpływ czynniki ekonomiczne, kulturalne, naukowe, które pobudzają aktywność czytelniczą. Widać to zwłaszcza w przypadku piśmiennictwa naukowego w miastach, w których istnieją ośrodki akademickie. Nie bez znaczenia jest też tradycja wydawnicza i tu w znacznie lepszej sytuacji są regiony i miasta, w których w okresie powojennym powstawały wydawnictwa niż te, w których tej tradycji nie było. Do regionów o mniejszej tradycji należą województwa wschodnie (podlaskie, podkarpackie), z wyjątkiem lubelskiego, województwa północne (zachodniopomorskie, warmińsko-mazurskie), z wyjątkiem pomorskiego (Gdańsk), a także województwo świętokrzyskie czy lubuskie. Do 1989 r., tj. do czasu istnienia w Polsce scentralizowanego rynku wydawniczego, oficyny wydawnicze zlokalizowane były głównie w wielkich miastach. 
Najwięcej było w Warszawie. Tu w okresie PRL ukazywało się ok.70\% wszystkich wydawanych książek. Jednak w kolejnych latach udział Warszawy w produkcji wydawniczej systematycznie malał, obniżając się do poziomu 36,5\% w 2010. Drugie miejsce zajmował Kraków z produkcją wydawniczą ok. 5\%, która w 2010 roku wzrosła dwukrotnie (11,3\%). W innych liczących się ośrodkach wydawniczych: Poznaniu, Wrocławiu i Łodzi, w ciągu ostatniego półwiecza nie nastąpiły jakieś radykalne zmiany (zob. tab.1).

Tabela 1. Zmiany ilościowe i procentowe tytułów książek wydanych w poszczególnych miastach w latach 1960, 1970, 2010

\begin{tabular}{|c|c|c|c|c|c|c|}
\hline \multirow[b]{2}{*}{ MIASTO } & \multicolumn{3}{|c|}{$\begin{array}{c}\text { LICZBA TYTUŁÓW KSIĄŻEK } \\
\text { OGÓŁEM W LATACH }\end{array}$} & \multicolumn{3}{|c|}{$\begin{array}{l}\text { UDZIAE PROCENTOWY MIAST } \\
\text { W PRODUKCJI KSIĄŻEK W LATACH }\end{array}$} \\
\hline & $\begin{array}{c}1960 \\
\text { (OGÓŁEM } \\
6879)\end{array}$ & $\begin{array}{c}1970 \\
\text { (OGÓ£EM } \\
10.038)\end{array}$ & $\begin{array}{c}2010 \\
\text { (OGÓŁEM } \\
29.539)\end{array}$ & 1960 & 1970 & 2010 \\
\hline Kraków & 320 & 559 & 3347 & 4,7 & 5,6 & 11,3 \\
\hline Łódź & 200 & 289 & 705 & 2,9 & 2,9 & 2,4 \\
\hline Poznań & 355 & 431 & 1904 & 5,2 & 4,3 & 6,4 \\
\hline Warszawa & 4980 & 6890 & 10768 & 72,4 & 68,6 & 36,5 \\
\hline Wrocław & 255 & 516 & 1039 & 3,7 & 5,1 & 3,5 \\
\hline
\end{tabular}

Źródło: Opracowanie własne na podstawie „Ruchu Wydawniczego w Liczbach” 1944-1973: zestawienia retrospektywne, tabela 3: Tytuły książek oraz gazet i czasopism według miejsca wydania oraz „Ruch Wydawniczy w Liczbach" 2010, tabela 2: Książki według miejsca wydania.

Od 1990 r. zauważalna jest stopniowa decentralizacja rynku wydawniczego. Ciągle jednak większość wydawców związana jest z wielkimi miastami, tutaj bowiem mieszczą się instytucje naukowe (szkoły wyższe, instytuty, towarzystwa naukowe), a także wyspecjalizowane wydawnictwa (techniczne, ekonomiczne, medyczne, rolnicze, prawnicze, szkolne). Warto jednak zauważyć, że zmieniają się proporcje wydawanych książek przez firmy wydawnicze i inne instytucje na korzyść tych pierwszych. I tak w 1980 r. proporcja ta wynosiła: 48,8\% - wydawcy, 51,2\% inne instytucje; w 1990 - 45,2\%: 54,8\%, w 1995 65,6\%: 34,4\%, w 2010 - 62,2\%: 37,8\% ${ }^{3}$.

Istnieją znaczne rozbieżności między województwami w wysokości produkcji wydawniczej w liczbach bezwzględnych oraz ich udziale procentowym w stosunku do ogółu tytułów książek wydawanych w kraju. Na ogół w województwach o niższej produkcji wydawniczej liczba wydawanych tytułów zwiększa się nawet dwukrotnie, ale ich udział procentowy pozostaje na niemal niezmienionym poziomie, co jest skutkiem zwiększającej się liczby tytułów książek ogółem. Największym producentem jest województwo mazowieckie, w tym Warszawa. Stąd pochodzi około 40\% wszystkich wydawanych w Polsce książek z okresu 1999-2010. Drugim województwem o wysokim wskaźniku (13\%) jest województwo małopolskie, kolejne miejsca zajmują województwa: śląskie (7,7\%), wielkopolskie (7,2\%), dolnośląskie (5,1\%). Najniższe wskaźniki (średnio poniżej 500 książek rocznie i poniżej $2 \%$ udziału globalnego) mają województwa: lubuskie,

\footnotetext{
${ }^{3}$ Obliczenia własne na podstawie tabeli 1: Wydawcy w „Ruchu Wydawniczym w Liczbach” za lata: 1980, 1990, 1995, 2010.
} 
opolskie, warmińsko-mazurskie, zachodniopomorskie, podlaskie, podkarpackie. Między 2,5\% a 4\% mieszczą się województwa: świętokrzyskie, łódzkie, lubelskie, pomorskie, kujawsko-pomorskie (zob. tab. 2).

Tabela 2. Suma tytułów książek w poszczególnych województwach i udział procentowy województw w produkcji książek ogółem w latach 1999-2010

\begin{tabular}{|c|c|c|c|}
\hline $\begin{array}{c}\text { WOJEWÓDZTWO } \\
\text { (WG LISTY RANGOWEJ } \\
\text { LICZBY TYTUŁÓW } \\
\text { KSIĄŻEK) }\end{array}$ & $\begin{array}{c}\text { LICZBA TYTUŁÓW } \\
\text { KSIAZŻEK 1999-2010 } \\
\text { (OGÓ£EM W KRAJU } \\
278216)\end{array}$ & $\begin{array}{l}\text { UDZIAE } \\
\text { PROCENTOWY } \\
\text { WOJEWÓDZTW } \\
\text { W PRODUKCJI } \\
\quad \text { KSIĄŻEK } \\
\end{array}$ & $\begin{array}{c}\text { ŚREDNIA ROCZNA } \\
\text { TYTUŁÓW } \\
\text { KSIĄŻEK (W KRAJU } \\
23184,7)\end{array}$ \\
\hline 1. Mazowieckie & 115676 & 41,6 & 9639,7 \\
\hline 2. Małopolskie & 36300 & 13,0 & 3025,0 \\
\hline 3. Śląskie & 21294 & 7,7 & 1774,5 \\
\hline 4. Wielkopolskie & 20102 & 7,2 & 1675,2 \\
\hline 5. Dolnośląskie & 14187 & 5,1 & 1182,2 \\
\hline 6. Kujawsko-pomorskie & 11007 & 4,0 & 917,2 \\
\hline 7. Pomorskie & 10301 & 3,7 & 858,4 \\
\hline 8. Lubelskie & 10077 & 3,6 & 839,7 \\
\hline 9. Łódzkie & 7790 & 2,8 & 649,2 \\
\hline 10. Świętokrzyskie & 7029 & 2,5 & 585,7 \\
\hline 11. Podkarpackie & 5924 & 2,1 & 493,7 \\
\hline 12. Podlaskie & 5002 & 1,8 & 416,8 \\
\hline 13. Zachodniopomorskie & 4976 & 1,8 & 414,7 \\
\hline 14. Warmińsko-mazurskie & 3678 & 1,3 & 306,5 \\
\hline 15. Opolskie & 2566 & 0,9 & 213,8 \\
\hline 16. Lubuskie & 2307 & 0,8 & 192,2 \\
\hline
\end{tabular}

Źródło: Obliczenia własne na podstawie „Ruchu Wydawniczego w Liczbach” z lat 1999-2010, tabela 2: Książki według miejsca wydania.

Porównanie wskaźników procentowych tytułów książek wydawanych w miastach wojewódzkich w latach 1999 i 2010 pozwala stwierdzić, że proporcje powoli zmieniają się na korzyść mniejszych miejscowości. Nie we wszystkich jednak województwach wskaźniki te wykazują te same tendencje. W niektórych miastach wojewódzkich (Warszawa, Kraków, Opole, Poznań, Wrocław) wskaźnik wydawanych tytułów książek w stosunku do ogólnej liczby książek wydawanych w całym województwie sięgał lub nawet przekraczał 90\%. Na przykładzie województwa mazowieckiego, największego producenta, widać wyraźnie, jak niewielki jest udział (10\%) innych dużych miast, które w przeszłości pełniły nawet rolę miast wojewódzkich (Ostrołęka, Ciechanów, Płock, Radom, Skierniewice, Siedlce). Są jednak województwa, gdzie wskaźnik wydań w terenie wynosi 50\% (woj. podkarpackie), a nawet 61\% (woj. śląskie, gdzie bardzo aktywne są miasta Częstochowa i Bielsko-Biała). Około 30\% tytułów wydawano poza głównymi miastami w województwach pomorskim i świętokrzyskim, około $25 \%$ w województwach: podlaskim, warmińsko-mazurskim, 
zachodnio-pomorskim. W 2010 r. wskaźniki te w porównaniu z r. 1999 ogólnie zmieniły się na korzyść innych miejscowości, niż miasta wojewódzkie (zob. tab. 3).

Tabela 3. Liczba tytułów książek wydawanych w województwach w roku 1999 i 2010 i wskaźniki procentowe udziału miast wojewódzkich.

\begin{tabular}{|c|c|c|c|c|}
\hline $\begin{array}{l}\text { WOJEWÓDZTWO/MIASTO } \\
\text { WOJEWÓDZKIE }\end{array}$ & $\begin{array}{l}\text { LICZBA TYTU- } \\
\text { ŁÓW KSIĄŻEKEK } \\
(1999)\end{array}$ & $\begin{array}{l}\text { LICZBA TYTU- } \\
\text { ŁÓW KSIĄŻEKEK } \\
(2010)\end{array}$ & $\begin{array}{c}\text { UDZIAE } \\
\text { PROCENTOWY } \\
\text { MIASTA } \\
\text { WOJEW. (1999) }\end{array}$ & $\begin{array}{c}\text { UDZIAE } \\
\text { PROCENTOWY } \\
\text { MIASTA } \\
\text { WOJEW. }(2010)\end{array}$ \\
\hline Dolnośląskie/Wrocław & $1183 / 1054$ & $1328 / 1039$ & 89,1 & 78,24 \\
\hline $\begin{array}{l}\text { Kujawsko-pomorskie/ } \\
\text { Bydgoszcz/Toruń* }\end{array}$ & $761 / 249 / 377$ & $1120 / 321 / 620$ & 82,3 & 84,0 \\
\hline Lubelskie/Lublin & $802 / 729$ & $1129 / 905$ & 91,0 & 80,2 \\
\hline $\begin{array}{l}\text { Lubuskie/Gorzów Wlkp/ } \\
\text { Zielona Góra** }\end{array}$ & $194 / 32 / 153$ & $264 / 60 / 120$ & 95,4 & 68,2 \\
\hline Łódzkie/Łódź & $570 / 459$ & $843 / 705$ & 80,5 & 83,6 \\
\hline Małopolskie/Kraków & $2188 / 2022$ & $3748 / 3347$ & 92,4 & 89,3 \\
\hline Mazowieckie/Warszawa & $8648 / 8098$ & $11948 / 10768$ & 93,6 & 90,1 \\
\hline Opolskie/Opole & $189 / 174$ & $305 / 245$ & 92,1 & 80,3 \\
\hline Podkarpackie/Rzeszów & $376 / 189$ & $706 / 348$ & 50,3 & 49,3 \\
\hline Podlaskie/Białystok & $262 / 200$ & $586 / 450$ & 76,3 & 76,8 \\
\hline Pomorskie/Gdańsk & $672 / 471$ & $1166 / 569$ & 70,1 & 48,8 \\
\hline Śląskie/Katowice & $1259 / 490$ & $2462 / 707$ & 38,9 & 28,7 \\
\hline Świętokrzyskie/Kielce & $350 / 252$ & $749 / 435$ & 72,0 & 58,1 \\
\hline $\begin{array}{l}\text { Warmińsko-mazurskie/ } \\
\text { Olsztyn }\end{array}$ & $246 / 185$ & $342 / 203$ & 75,2 & 59,4 \\
\hline Wielkopolskie/Poznań & $1365 / 1232$ & $2292 / 1904$ & 90,3 & 83,1 \\
\hline $\begin{array}{l}\text { Zachodnio-pomorskie/ } \\
\text { Szczecin }\end{array}$ & $415 / 318$ & $551 / 415$ & 76,6 & 75,3 \\
\hline
\end{tabular}

Źródło: Obliczenia własne na podstawie „Ruchu Wydawniczego w Liczbach” z lat 1999 - 2010, tabela 2: Książki według miejsca wydania.

"Województwa kujawsko-pomorskie i lubuskie mają po dwa miasta wojewódzkie, co uwzględnia „Ruch Wydawniczy w Liczbach".

Tabela 3 ilustruje stosunek liczby tytułów książek wydanych ogółem w danym województwie do liczby wydanych w mieście wojewódzkim. Na podstawie przedstawionych danych można stwierdzić, że między 1999 a 2010 r. udział mniejszych miejscowości w rynku wydawniczym zwiększył się w wielu województwach: w lubuskim (o ok. 27\%), pomorskim (o 21\%), warmińsko-mazurskim (o 16\%), świętokrzyskim (o 14\%), opolskim (o 12\%), dolnośląskim (ok.11\%), lubelskim (o 11\%), śląskim (o 10\%) i wielkopolskim (o 7\%). Oznacza to, że w tych województwach nastąpiła dekoncentracja oficyn wydawniczych na korzyść mniejszych ośrodków. Na niemal niezmienionym poziomie pozostały wskaźniki procentowe w województwach: podlaskim (o 0,35\%), podkarpackim (1\%), zachodniopomorskim (1,3\%), 
małopolskim (3\%), mazowieckim (3\%). W województwach łódzkim i kujawsko-pomorskim wystąpiła tendencja odwrotna, mianowicie udział miast wojewódzkich zwiększył się o 3\% w Łodzi i 1,7\% łącznie w Toruniu i Bydgoszczy.

\section{Książki naukowe}

Wydawcami książek naukowych (w tym podręczników akademickich) są na ogół wyspecjalizowane oficyny lub instytucje naukowe, a zatem liczba wydawanych tytułów w poszczególnych województwach ma związek z infrastrukturą naukową, głównie liczbą wyższych uczelni, instytutów naukowych branżowych i PAN, towarzystw naukowych.

Tabela 4. Liczba tytułów książek naukowych (z podręcznikami akademickimi) wydanych w województwach oraz ich udział w produkcji książek w kraju w latach 1999-2010

\begin{tabular}{|c|c|c|c|}
\hline $\begin{array}{c}\text { WOJEWÓDZTWO } \\
\text { (WG LISTY RANGOWEJ } \\
\text { LICZBY TYTUEÓW } \\
\text { KSIĄŻEK NAUKOWYCH) }\end{array}$ & $\begin{array}{c}\text { LICZBA TYTUŁÓW } \\
\text { KSIĄŻEK } \\
\text { NAUKOWYCH } \\
\text { W LATACH 1999- } \\
\text { 201O (OGÓ£EM } \\
\text { W KRAJU 118650) }\end{array}$ & $\begin{array}{c}\text { UDZIAE } \\
\text { PROCENTOWY } \\
\text { WOJEWÓDZTW } \\
\text { W PRODUKCJI } \\
\text { KSIĄŻEK } \\
\text { NAUKOWYCH }\end{array}$ & $\begin{array}{c}\text { ŚREDNIA ROCZNA } \\
\text { TYTUŁÓW } \\
\text { KSIĄŻEK } \\
\text { NAUKOWYCH } \\
\text { (W KRAJU 9887,5) }\end{array}$ \\
\hline 1. Mazowieckie & 40584 & 34,2 & 3382 \\
\hline 2. Małopolskie & 15516 & 13,1 & 1293 \\
\hline 3. Śląskie & 10625 & 9,0 & 885,4 \\
\hline 4. Wielkopolskie & 8341 & 7,0 & 691,0 \\
\hline 5. Dolnośląskie & 7653 & 6,5 & 637,7 \\
\hline 6. Lubelskie & 6266 & 5,3 & 522,2 \\
\hline 7. Kujawsko-pomorskie & 5883 & 4,9 & 490,2 \\
\hline 8. Pomorskie & 4770 & 4,0 & 397,5 \\
\hline 9. Łódzkie & 4247 & 3,6 & 355,6 \\
\hline 10. Zachodniopomorskie & 3172 & 2,7 & 264,3 \\
\hline 11. Podkarpackie & 2693 & 2,3 & 224,4 \\
\hline 12. Podlaskie & 2128 & 1,8 & 177,3 \\
\hline 13. Warmińsko-mazurskie & 2082 & 1,7 & 173,5 \\
\hline 14. Świętokrzyskie & 1899 & 1,6 & 158,2 \\
\hline 15. Opolskie & 1706 & 1,4 & 142,2 \\
\hline 16. Lubuskie & 1085 & 0,9 & 90,4 \\
\hline
\end{tabular}

Źródło: Obliczenia własne na podstawie „Ruchu Wydawniczego w Liczbach” z lat 1999-2010, tabela 2: Książki według miejsca wydania.

Porównując wielkości wydanych książek naukowych w poszczególnych województwach w okresie 12 lat widać wyraźnie podział na cztery grupy: a) dominujące województwo mazowieckie (34\% produkcji krajowej); b) województwa, w których wydaje się rocznie od 1300 do ok. 500 (między 13 a 5\%) tytułów książek naukowych (małopolskie, śląskie, wielkopolskie, 
dolnośląskie, lubelskie, kujawsko-pomorskie); c) województwa, które wydają średnio od 500 do ok. 200 (między 4 a 2,3\%) tytułów książek rocznie (pomorskie, łódzkie, zachodniopomorskie, podkarpackie); d) województwa, w których wydaje się średnio rocznie od 200 do 100 (poniżej 2\%) tytułów (podlaskie, warmińsko-mazurskie, świętokrzyskie, opolskie, lubuskie).

Dominacja województwa mazowieckiego wynika $\mathrm{z}$ istnienia w Warszawie największej sieci uczelnianej, instytutów PAN, instytutów branżowych, towarzystw naukowych. W drugiej grupie znalazły się województwa z wieloma szkołami wyższymi, w tym największymi uniwersytetami (Uniwersytet Jagielloński, Uniwersytet Wrocławski, Uniwersytet Adama Mickiewicza, Katolicki Uniwersytet Lubelski, Uniwersytet Marii Skłodowskiej-Curie, Uniwersytet Mikołaja Kopernika, Uniwersytet Śląski). Trzecia i czwarta grupa obejmuje województwa posiadające wprawdzie szkoły wyższe, ale o mniejszej liczebności studentów i kadry naukowej lub o krótszej tradycji, jak Uniwersytet Opolski, Uniwersytet w Białymstoku, Uniwersytet Rzeszowski, Uniwersytet Warmińsko-Mazurski, Uniwersytet Zielonogórski czy Uniwersytet Jana Kochanowskiego w Kielcach. Niewątpliwie, na sytuację wydawniczą książek naukowych rzutuje też aktywność całego środowiska naukowego, w tym działalność niepublicznych szkół wyższych powstałych po $1990 \mathrm{r}$.

Tabela 5. Liczba tytułów podręczników akademickich wydanych w poszczególnych wojewódz-

twach oraz ich udział w produkcji podręczników akademickich w kraju w latach 1999-2010

\begin{tabular}{|c|c|c|c|}
\hline $\begin{array}{l}\text { WOJEWÓDZTWO } \\
\text { (WG LISTY RANGOWEJ } \\
\text { LICZBY TYTUEÓW } \\
\text { PODRĘCZNIKÓW } \\
\text { AKADEMICKICH }\end{array}$ & $\begin{array}{l}\text { LICZBA TYTUŁÓW } \\
\text { PODRĘCZNIKÓW } \\
\text { AKADEMICKICH } \\
\text { W LATACH 1999- } \\
\text { 2010 W KRAJU } \\
\text { (OGÓ£EM 21084) } \\
\end{array}$ & $\begin{array}{c}\text { UDZIAE } \\
\text { PROCENTOWY } \\
\text { WOJEWÓDZTW } \\
\text { W PRODUKCJI } \\
\text { PODRĘCZNIKÓW } \\
\text { AKADEMICKICH }\end{array}$ & $\begin{array}{l}\text { ŚREDNIA ROCZNA } \\
\text { PODRĘCZNIKÓW } \\
\text { AKADEMICKICH } \\
\text { (W KRAJU 1757) }\end{array}$ \\
\hline 1. Mazowieckie & 8151 & 38,7 & 679,2 \\
\hline 2. Małopolskie & 2146 & 10,2 & 178.8 \\
\hline 3. Śląskie & 1879 & 8,9 & 156,6 \\
\hline 4. Wielkopolskie & 1776 & 8,4 & 148,0 \\
\hline 5. Dolnośląskie & 1411 & 6,7 & 117,6 \\
\hline 6. Pomorskie & 895 & 4,2 & 74,6 \\
\hline 7. Zachodniopomorskie & 682 & 3,2 & 56,8 \\
\hline 8. Lubelskie & 681 & 3,2 & 56,7 \\
\hline 9. Podkarpackie & 670 & 3,2 & 55,8 \\
\hline 10. Łódzkie & 656 & 3,1 & 54,7 \\
\hline 11. Kujawsko-pomorskie & 624 & 3,0 & 52,0 \\
\hline 12. Warmińsko-mazurskie & 454 & 2,1 & 37,8 \\
\hline 13. Świętokrzyskie & 380 & 1,8 & 31,7 \\
\hline 14. Podlaskie & 353 & 1,7 & 29,4 \\
\hline 15. Opolskie & 211 & 1,0 & 17,6 \\
\hline 16. Lubuskie & 115 & 0,5 & 9,6 \\
\hline
\end{tabular}

Źródło: Obliczenia własne na podstawie „Ruchu Wydawniczego w Liczbach” z lat 1999-2010, tabela 2: Książki według miejsca wydania. 
Lista rangowa województw według liczby wydanych podręczników akademickich w części pokrywa się z kolejnością ustaloną dla książek naukowych, ale już od 6. miejsca widoczne są różnice. Województwo pomorskie z 8. miejsca w przypadku książek naukowych przesunęło się na 6. w produkcji podręczników akademickich. Podobnie jest z województwem zachodniopomorskim - ma ono 10. miejsce w produkcji książek naukowych, ale 7. w przypadku podręczników; podkarpackie - 11. miejsce w produkcji książek naukowych, ale 9. w przypadku podręczników akademickich. Świadczy to o aktywności szkół wyższych na tym terenie. Są też sytuacje odwrotne. Województwo kujawsko-pomorskie zajmowało 7. miejsce w produkcji książek naukowych, ale 11. w przypadku podręczników; województwo podlaskie - 12. miejsce w produkcji książek naukowych, ale 14. w przypadku podręczników akademickich. Liczby wydawanych tytułów podręczników akademickich niewątpliwie mają związek ze szkolnictwem wyższym oraz wielkością i aktywnością środowiska akademickiego w danym województwie.

Tabela 6. Zmiany ilościowe i procentowe książek naukowych (z podręcznikami akademickimi) wydanych w poszczególnych miastach w latach 1999 i 2010

\begin{tabular}{|c|c|c|c|c|}
\hline $\begin{array}{c}\text { MIASTO } \\
\text { WOJEWÓDZKIE } \\
\text { (ALFABETYCZNIE) }\end{array}$ & $\begin{array}{l}\text { LICZBA } \\
\text { TYTUŁÓW } \\
\text { W 1999 R. } \\
\text { (OGÓŁEM } \\
\text { W KRAJU 8289) }\end{array}$ & $\begin{array}{c}\text { LICZBA } \\
\text { TYTUŁÓW } \\
\text { W 2O1O R. } \\
\text { (OGÓŁEM } \\
\text { W KRAJU 13.015) }\end{array}$ & $\begin{array}{c}\text { UDZIAE } \\
\text { PROCENTOWY } \\
\text { MIASTA } \\
\text { W } 1999 \text { R. }\end{array}$ & $\begin{array}{c}\text { UDZIAE } \\
\text { PROCENTOWY } \\
\text { MIASTA } \\
\text { W 2010 R. }\end{array}$ \\
\hline Białystok & 115 & 232 & 1,4 & 1,8 \\
\hline Bydgoszcz & 119 & 156 & 1,4 & 1,2 \\
\hline Gdańsk & 210 & 344 & 2,5 & 2,6 \\
\hline Gorzów Wlkp. & 9 & 33 & 0,1 & 0,25 \\
\hline Katowice & 283 & 407 & 3,4 & 3,1 \\
\hline Kielce & 108 & 152 & 1,3 & 1,2 \\
\hline Kraków & 954 & 1512 & 11,5 & 11,6 \\
\hline Lublin & 493 & 613 & 5,9 & 4,7 \\
\hline Łódź & 286 & 408 & 3,4 & 3,1 \\
\hline Olsztyn & 120 & 143 & 1,4 & 1,1 \\
\hline Opole & 121 & 177 & 1,5 & 1,4 \\
\hline Poznań & 530 & 798 & 6,4 & 6,1 \\
\hline Rzeszów & 121 & 208 & 1,5 & 1,6 \\
\hline Szczecin & 201 & 260 & 2,4 & 2,0 \\
\hline Toruń & 232 & 441 & 2,8 & 3,4 \\
\hline Zielona Góra & 61 & 92 & 0,7 & 0,7 \\
\hline Warszawa & 2692 & 4229 & 32,5 & 32,5 \\
\hline Wrocław & 620 & 703 & 7,5 & 5,4 \\
\hline
\end{tabular}

Źródło: Obliczenia własne na podstawie „Ruchu Wydawniczego w Liczbach” z lat 1999-2010, tabela 2: Książki według miejsca wydania. 
Na podstawie porównania wskaźników procentowych z tabeli 6 widać, że w przypadku książek naukowych wydawcy pozostają w wielkich miastach. Głównym ośrodkiem wydawniczym książek naukowych jest Warszawa - 32,5\% książek naukowych wydawanych w kraju, drugie miejsce zajmuje Kraków z 11,5\%. Niewielkie różnice procentowe zanotowano we Wrocławiu - ok.2\% spadku oraz Lublina - około 1,2\% mniej. W pozostałych ośrodkach zmiany są minimalne (w granicach 0,5\%). Wskaźniki te potwierdzają koncentrację ośrodków naukowych i oficyn naukowych w miastach wojewódzkich.

\section{Literatura piękna}

Wydawanie literatury pięknej nie jest uzależnione od infrastruktury naukowej czy kulturalnej w takim stopniu, jak wydawanie książek naukowych. Niemniej jednak ma ono związek z wcześniejszym funkcjonowaniem wydawnictw literackich, a te w okresie PRL były lokowane w miastach wojewódzkich: „Czytelnik” i PIw (Warszawa), Wydawnictwo Literackie (Kraków), w latach pięćdziesiątych powstały: Wydawnictwo Morskie (Gdańsk), Wydawnictwo Łódzkie, Wydawnictwo Poznańskie, Lubelska Spółdzielnia Wydawnicza (przemianowana w 1961 r. na Wydawnictwo Lubelskie), Wydawnictwo „Śląsk” (Katowice), w latach osiemdziesiątych - Wydawnictwo Dolnośląskie (Wrocław) z filii Wydawnictwa Literackiego. Literatura piękna była też wydawana przez oddziały regionalne Związku Literatów Polskich (np.w Białymstoku, Ciechanowie, Gorzowie Wielkopolskim, Rzeszowie, Słupsku). Mimo restrukturyzacji i pojawienia się po 1989 r. nowych wydawnictw literackich, część dawnych oficyn literackich dosyć dobrze sobie radzi w nowych warunkach rynkowych (np.: „Nasza Księgarnia”, Wydawnictwo Literackie, Wydawnictwo Dolnośląskie), ale niektóre z nich upadły (np. Ossolineum, Państwowy Instytut Wydawniczy, Wydawnictwo Łódzkie). Po 1989 r. pojawiło się wiele nowych oficyn wydających znaczną liczbę tytułów literatury pięknej (np.Zielona Sowa, Zysk i S-ka, Amber, Rebis, Świat Książki czy Arlekin (wydający serię tzw. harlekinów).

Tabela 7. Liczba tytułów literatury pięknej wydanych w poszczególnych województwach oraz ich udział w produkcji książek w latach 1999-2010

\begin{tabular}{|c|c|c|c|}
\hline $\begin{array}{c}\text { WOJEWÓDZTWO } \\
\text { (WG LISTY RANGOWEJ } \\
\text { LICZBY TYTUŁÓW } \\
\text { LITERATURY PIĘKNEJ) }\end{array}$ & $\begin{array}{c}\text { LICZBA TYTU£ÓW } \\
\text { KSIĄŻEK } \\
\text { LITERATURY } \\
\text { PIĘKNEJ W LATACH } \\
\text { 1999-2O1O (OGÓ£EM } \\
\text { W KRAJU 57261) }\end{array}$ & $\begin{array}{c}\text { UDZIAE } \\
\text { PROCENTOWY } \\
\text { WOJEWÓDZTW } \\
\text { W PRODUKCJI } \\
\text { KSIĄŻEK } \\
\text { LITERATURY } \\
\text { PIĘKNEJ }\end{array}$ & $\begin{array}{l}\text { ŚREDNIA ROCZNA } \\
\text { TYTULÓW } \\
\text { KSIĄŻEK } \\
\text { LITERATURY } \\
\text { PIĘKNEJ (W KRAJU } \\
4771,7)\end{array}$ \\
\hline 1. Mazowieckie & 26721 & 46,7 & 2226,7 \\
\hline 2. Małopolskie & 7210 & 12,6 & 600,8 \\
\hline 3. Wielkopolskie & 4796 & 8,4 & 399,7 \\
\hline 4. Śląskie & 3284 & 5,7 & 273,7 \\
\hline 5. Dolnośląskie & 2634 & 4,6 & 219,5 \\
\hline 6. Łódzkie & 2275 & 4,0 & 189,6 \\
\hline
\end{tabular}




\begin{tabular}{|c|c|c|c|}
\hline $\begin{array}{c}\text { WOJEWÓDZTWO } \\
\text { (WG LISTY RANGOWEJ } \\
\text { LICZBY TYTUEÓW } \\
\text { LITERATURY PIĘKNEJ) }\end{array}$ & $\begin{array}{l}\text { LICZBA TYTULÓW } \\
\text { KSIĄŻEK } \\
\text { LITERATURY } \\
\text { PIĘKNEJ W LATACH } \\
\text { 1999-2O1O (OGÓ£EM } \\
\text { W KRAJU 57261) }\end{array}$ & $\begin{array}{c}\text { UDZIAE } \\
\text { PROCENTOWY } \\
\text { WOJEWÓDZTW } \\
\text { W PRODUKCJI } \\
\text { KSIĄŻEK } \\
\text { LITERATURY } \\
\text { PIĘKNEJ }\end{array}$ & $\begin{array}{l}\text { ŚREDNIA ROCZNA } \\
\text { TYTUŁÓW } \\
\text { KSIĄŻEK } \\
\text { LITERATURY } \\
\text { PIĘKNEJ (W KRAJU } \\
4771,7)\end{array}$ \\
\hline 7. Lubelskie & 1734 & 3,0 & 144,5 \\
\hline 8. Kujawsko-pomorskie & 1694 & 2,9 & 141,2 \\
\hline 9. Świętokrzyskie & 1414 & 2,5 & 117,8 \\
\hline 10. Pomorskie & 1248 & 2,2 & 104,0 \\
\hline 11. Podlaskie & 1006 & 1,8 & 83,8 \\
\hline 12. Podkarpackie & 880 & 1,5 & 73,3 \\
\hline 13. Warmińsko-mazurskie & 804 & 1,4 & 67,0 \\
\hline 14. Zachodniopomorskie & 756 & 1,3 & 63,0 \\
\hline 15. Lubuskie & 560 & 1,0 & 46,7 \\
\hline 16. Opolskie & 245 & 0,4 & 20,4 \\
\hline
\end{tabular}

Źródło: Obliczenia własne na podstawie „Ruchu Wydawniczego w Liczbach” z lat 1999-2010, tabela 2: Książki według miejsca wydania.

Przedstawione w tabeli 7 zestawienie liczby wydanych książek literackich w poszczególnych województwach, wskazuje, że prawie połowę tytułów wydano w województwie mazowieckim (46,7\%). Podobnie jak w produkcji książek naukowych, tu także wiodącą grupę stanowią województwa: małopolskie, wielkopolskie, śląskie, dolnośląskie. Poniżej $2 \%$ literatury pięknej wydają województwa: podlaskie, podkarpackie, warmińsko-mazurskie, zachodnio-pomorskie, lubuskie, opolskie. Warto zauważyć dosyć wysoki wskaźnik województwa łódzkiego (4\% wobec $2,8 \%$ książek ogółem) oraz niższe wskaźniki województwa pomorskiego (2,2\% wobec $3,7 \%$ książek ogółem) i śląskiego (5,7\% wobec $7,7 \%$ książek ogółem), które z kolei mają wyższe wskaźniki książek naukowych.

Analizując wielkość produkcji wydawniczej książek literackich w miastach wojewódzkich należy zwrócić uwagę na powiększanie się liczby tytułów, natomiast nie jest to równoznaczne ze zwiększaniem się wskaźnika udziału procentowego danego miasta w stosunku do ogólnej liczby tytułów książek literackich w kraju. Największym ośrodkiem wydawniczym literatury pięknej jest Warszawa, gdzie w 1999 r. ukazywała się połowa książek literackich (49\%), w roku 2010 wskaźnik zmniejszył się o ok.4\%. O połowę zmniejszyły się wskaźniki procentowe w takich miastach jak: Gdańsk, Olsztyn, Wrocław. Aż 10-krotnie zmniejszył się wskaźnik w Zielonej Górze. Na niezmienionym poziomie pozostały wskaźniki procentowe produkcji książki literackiej w takich miastach, jak: Białystok, Bydgoszcz, Katowice, Kraków, Lublin, Opole. Z kolei, w Łodzi, Poznaniu, Rzeszowie, Toruniu produkcja nieznacznie zwiększyła się między rokiem 1999 a 2010. Można zatem uznać, że również literatura piękna jest głównie wydawana w wielkich miastach, choć widoczne są tendencje decentralizacyjne. 
Tabela 8. Zmiany ilościowe i procentowe tytułów literatury pięknej wydanych w poszczególnych miastach w latach 1999 i 2010

\begin{tabular}{|l|c|c|c|c|}
\hline $\begin{array}{c}\text { MIASTO } \\
\text { WOJEWÓDZKIE }\end{array}$ & $\begin{array}{c}\text { LICZBA } \\
\text { TYTUEÓW 1999 } \\
\text { (OGÓ£EM 3560) }\end{array}$ & $\begin{array}{c}\text { LICZBA TYTU- } \\
\text { EÓW 2010 } \\
\text { (OGÓ£EM 6190) }\end{array}$ & $\begin{array}{c}\text { UDZIAE } \\
\text { PROCENTOWY } \\
\text { MIASTA W 1999 R. }\end{array}$ & $\begin{array}{c}\text { UDZIAE } \\
\text { PROCENTOWY } \\
\text { MIASTA W 2010 R. }\end{array}$ \\
\hline Białystok & 38 & 71 & 1,1 & 1,1 \\
\hline Bydgoszcz & 33 & 55 & 0,9 & 0,9 \\
\hline Gdańsk & 54 & 41 & 1,5 & 0,7 \\
\hline Gorzów Wlkp. & 4 & 6 & 0,1 & 0,1 \\
\hline Katowice & 73 & 127 & 2,0 & 2,0 \\
\hline Kielce & 36 & 83 & 1,0 & 1,3 \\
\hline Kraków & 305 & 683 & 11,4 & 11,0 \\
\hline Lublin & 93 & 163 & 2,6 & 2,6 \\
\hline Łódź & 66 & 165 & 1,9 & 0,4 \\
\hline Olsztyn & 29 & 26 & 0,8 & 0,2 \\
\hline Opole & 6 & 14 & 0,2 & 8,4 \\
\hline Poznań & 264 & 519 & 7,4 & 1,0 \\
\hline Rzeszów & 7 & 62 & 0,2 & 1,0 \\
\hline Szczecin & 31 & 61 & 0,9 & 1,2 \\
\hline Toruń & 18 & 77 & 0,5 & 44,9 \\
\hline Warszawa & 1730 & 2780 & 49,0 & 1,9 \\
\hline Wrocław & 134 & 115 & 3,8 & 0,1 \\
\hline Zielona Góra & 59 & 9 & 1,6 & \\
\hline
\end{tabular}

Źródło: Obliczenia własne na podstawie „Ruchu Wydawniczego w Liczbach” z lat 1999-2010, tabela 2: Książki według miejsca wydania.

\section{Wnioski}

Podsumowując analizę geografii produkcji wydawniczej książek w latach 1999-2010, warto zwrócić uwagę na pewne różnice zachodzące pomiędzy województwami w liczbie tytułów książek ogółem, książek naukowych i podręczników akademickich oraz literatury pięknej (zob. tab. 9).

Trzy województwa: mazowieckie, małopolskie i dolnośląskie zajmują jednakowe miejsca na liście rangowej w produkcji wszystkich typów książek. W pozostałych województwach występują różnice w stosunku do miejsca województwa na liście rangowej ze względu na ogólną liczbę książek (pierwsza kolumna), czasem na korzyść książki naukowej (lubelskie, zachodniopomorskie, warmińsko-mazurskie), czasem podręczników akademickich (podkarpackie, pomorskie, warmińsko-mazurskie, zachodniopomorskie) lub książki literackiej (łódzkie, świętokrzyskie, wielkopolskie, podlaskie, lubelskie, lubuskie). 
Pewne dysproporcje występują w województwach: świętokrzyskim, które zajmuje ogólnie 10. miejsce, ale w przypadku książki naukowej niższe, bo 14.; województwo zachodniopomorskie zajmuje ogólnie 13. miejsce, ale w przypadku książki naukowej ma pozycję wyższą - 10.; województwo łódzkie mieści się na pozycji 9., ale w przypadku książki literackiej jego miejsce jest znacznie wyższe - 6.; województwo pomorskie ma ogólnie 7. miejsce, ale w przypadku książki literackiej - 10. W innych województwach dysproporcje są minimalne.

Tabela 9. Listy rangowe województw według liczby tytułów książek ogółem, książek naukowych (z podręcznikami akademickimi), podręczników akademickich i literatury pięknej w latach 1999-2010

\begin{tabular}{|c|c|c|c|c|}
\hline \multirow[b]{2}{*}{$\begin{array}{l}\text { WOJEWÓDZTWO } \\
\text { (ALFABETYCZNIE) }\end{array}$} & \multicolumn{4}{|c|}{ LISTA RANGOWA WOJEWÓDZTW WEDŁUG LICZBY TYTUŁÓW } \\
\hline & $\begin{array}{c}\text { KSIÁŻEK } \\
\text { OGÓ£EM } \\
\text { W LATACH } \\
1999-2010\end{array}$ & $\begin{array}{c}\text { KSIĄŻEK } \\
\text { NAUKOWYCH } \\
\text { (Z PODR. AKAD.) }\end{array}$ & $\begin{array}{l}\text { PODRĘCZNIKÓW } \\
\text { AKADEMICKICH }\end{array}$ & $\begin{array}{l}\text { LITERATURY } \\
\text { PIĘKNEJ }\end{array}$ \\
\hline Dolnośląskie & 5 & 5 & 5 & 5 \\
\hline Kujawsko-pomorskie & 6 & 7 & 11 & 8 \\
\hline Lubelskie & 8 & 6 & 8 & 7 \\
\hline Lubuskie & 16 & 16 & 16 & 15 \\
\hline Łódzkie & 9 & 9 & 10 & 6 \\
\hline Małopolskie & 2 & 2 & 2 & 2 \\
\hline Mazowieckie & 1 & 1 & 1 & 1 \\
\hline Opolskie & 15 & 15 & 15 & 16 \\
\hline Podkarpackie & 11 & 11 & 9 & 12 \\
\hline Podlaskie & 12 & 12 & 14 & 11 \\
\hline Pomorskie & 7 & 8 & 6 & 10 \\
\hline Śląskie & 3 & 3 & 3 & 4 \\
\hline Świętokrzyskie & 10 & 14 & 13 & 9 \\
\hline Warmińsko-mazurskie & 14 & 13 & 12 & 13 \\
\hline Wielkopolskie & 4 & 4 & 4 & 3 \\
\hline Zachodniopomorskie & 13 & 10 & 7 & 14 \\
\hline
\end{tabular}

Źródło: Obliczenia własne.

Przedstawiona analiza geografii wydawniczej w latach 1999-2010 pozwala stwierdzić, że dominującą pozycję zajmuje województwo mazowieckie i Warszawa. Druga grupa województw o stosunkowo wysokim udziale procentowym to: małopolskie, śląskie (gdzie oprócz Katowic silnymi ośrodkami wydawniczymi są Bielsko-Biała i Częstochowa), wielkopolskie i dolnośląskie. Są to województwa o wysokim poziomie ekonomicznym i dużej koncentracji infrastruktury kulturalnej i naukowej. Na średnim poziomie plasują się województwa: pomorskie, kujawsko-pomorskie, łódzkie, lubelskie. W miastach wojewódzkich tej grupy znajdują się wyższe uczelnie (uniwersytety, politechniki, akademie medyczne) o długiej tradycji. Najniższe wskaźniki mają województwa tzw. ściany wschodniej: warmińsko-mazurskie, 
podlaskie, podkarpackie, świętokrzyskie oraz obszary północno-zachodnie: województwa zachodniopomorskie i lubuskie. Są to województwa o niższym poziomie ekonomicznym, a co za tym idzie, także o niższej infrastrukturze naukowej i kulturowej. Wyjątkiem może tu być województwo opolskie, którego poziom ekonomiczny jest stosunkowo wysoki, natomiast produkcja wydawnicza jest stosunkowo niska (15 miejsce wśród 16 województw).

Warto też zauważyć, że w liczbach bezwzględnych produkcja wydawnicza książek we wszystkich województwach między rokiem 1999 a 2010 zwiększyła się, jednak ich udział procentowy w ogólnej produkcji wydawniczej jest bardzo zróżnicowany i mieści się w przedziale od 0,8\% (lubuskie), 0,9\% (opolskie) do 41,6\% (mazowieckie).

Kolejne spostrzeżenie dotyczy zmniejszania się produkcji wydawniczej w wielkich miastach i przenoszenia jej poza miasta wojewódzkie. Nie jest to proces radykalny, ale zmiany między rokiem 1999 a 2010 są już widoczne i w wielu województwach wynoszą ponad 10\% na korzyść mniejszych ośrodków. W przypadku książek naukowych należy uznać, że ośrodkami ich wydawania są ciągle duże miasta, w których skupione są wyższe uczelnie o dłuższych tradycjach naukowych.

\title{
Bibliografia
}

\section{Źródła}

„Ruch Wydawniczy w Liczbach”, roczniki z lat 1999-2010. Warszawa: BN.

„Ruch Wydawniczy w Liczbach”: zestawienia retrospektywne 1944-1973. Warszawa: BN 1974.

\section{Opracowania}

Kocójowa, M. (1995). Metoda typograficzna w badaniach nad ksiazka i biblioteka. W: Studia bibliograficzno-bibliologiczne: praca zbiorowa dla uczczenia 45-lecia pracy naukowej profesora dra hab. Wiesława Bieńkowskiego. Pod red. Marii Kocójowej, Kraków: Wydaw. uJ, 165-174.

Kraśko, N. (2001). Instytucje wydawnicze w II Rzeczypospolitej. Warszawa: BN.

Nowak, P. (2003). Topografia polskiego ruchu wydawniczego w świetle tzw. Europy regionów. W: Studia nad językiem, informacją i komunikacja. Pod red. W. Krzemińskiej i P. Nowaka. Poznań: „Sorus”,51-62.

\section{Book Publishing Geography in Poland (1999-2010)}

\begin{abstract}
Purpose: The aim of this paper is the presentation of the book publishing geography in Poland, 1999-2010 (from the last country administrative division) by provinces (voivodeships).

Methods: The applied research method was the analysis the statistics of books (number of titles) included in the „Polish Publishing in Figures” - the official Polish statistical yearbook.

Results and conclusions: Based on the rang lists of particular types of books was presented the territorial division of book publishing in Poland. It was found that the largest center for publishing is Mazowsze especially Warszawa, although its share is slowly declining in favor of other cities. The next regions and cities are: Małopolska (Kraków), Śląsk (Katowice), Wielkopolska (Poznań), Dolny Śląsk (Wrocław). The lowest rates are publishing Lubuskie (Zielona Góra), Opolskie (Opole), Warmia and Mazury (Olsztyn), Podlasie (Białystok). Generally, the slow process of decentralization of publishing is visible.
\end{abstract}


Originality/value: The statistical data for the book publishing in territorial, chronological and typological aspects are documenting the changes occurring on the Polish publishing market. There is no literature about this type of analysis of Polish publishing in the period 1999-2010.

Keywords Book publishing, Poland (1999-2010). Book statistic data, Poland. „Polish Publishing in Figures". Publishing geography of Poland (1999-2010).

Dr hab. JADWIGA SADOWSKA, prof. UwB jest kierownikiem Zakładu Informacji Naukowej i Bibliotekoznawstwa na Uniwersytecie w Biatymstoku. Jest autorką ok. 200 publikacji, w tym ksiażek: Hasta przedmiotowe w teorii Adama Łysakowskiego i praktyce „Przewodnika Bibliograficznego”(Warszawa 2000), Język haset przedmiotowych Biblioteki Narodowej. Studium analityczno-porównawcze (Warszawa 2003), Książi i czasopisma w Polsce w świetle liczb (1990-2010) (Biatystok 2013). 